\title{
Jurisprudentie
}

\section{Stoian t. Roemenië: stap terug of status quo? Een EHRM-casus over het recht op inclusief onderwijs}

EHRM 25 juni 2019, 289/14 (Stoian/Roemenië)

Dra. M. Spinoy (M.Jur.) en dr. J. Lievens (LL.M.)*

\section{Introductie}

1. Hoe bieden we kinderen met specifieke onderwijsbehoeften optimaal onderwijs? Wanneer is onderwijs 'passend'? Welke eisen stelt het recht op onderwijs? Het zijn vragen die noch pedagogisch noch in het maatschappelijk debat een eensluidend antwoord kennen en die tot controverse leiden. Internationaalrechtelijk is deze vraag echter grotendeels beantwoord. Het breed geratificeerde VN-verdrag inzake de Rechten van Personen met een Handicap (hierna: VN-verdrag Handicap) stelt immers onomwonden dat kinderen met een handicap recht hebben op inclusief onderwijs. ${ }^{1}$ Artikel $24 \mathrm{VN}-v e r-$ drag Handicap verplicht staten onder meer tot het waarborgen van een inclusief onderwijssysteem en

* Dra. M. (Marie) Spinoy is doctoraatsonderzoeker aan het Leuven Centre for Public Law (KU Leuven). Ze doet onderzoek op het gebied van non-discriminatie. Dr. J. (Johan) Lievens is universitair docent staatsrecht en onderwijsrecht aan de VU Amsterdam. Hij is tevens verbonden aan de Université de Namur en het Leuven Centre for Public Law (KU Leuven).

1. Het Verdrag trad in Nederland in werking op 14 juli 2016 (Trb. 2016 105). Zie ook J. Wevers, 'Wij zullen segregatie in het onderwijs steeds minder gaan accepteren', Balans, https://balansdigitaal.nl/nieuws/ zullen-segregatie-onderwijs-steeds-minder-gaan-accepteren/ over de wijze waarop het College voor de Rechten van de Mens waakt over de omzetting van de verdragsverplichtingen in Nederland. het voorzien van redelijke aanpassingen. Bovendien vereist het op termijn de afschaffing van gesegregeerde onderwijssystemen. ${ }^{2}$ Deze overgang naar een volwaardig inclusief onderwijsstelsel gaat in veel landen gepaard met kinderziektes. ${ }^{3}$ Ook in landen als Nederland en België, waar historisch geopteerd is voor een stelsel van speciaal onderwijs, verloopt dit proces niet zonder problemen. ${ }^{4}$ Beide landen kampen met zorgen en klachten van ouders en scholen, die al dan niet tot een juridische afhandeling leiden. ${ }^{5}$ Voor toekomstige klachten is dan ook rele-

2. General Comment no. 4 bij het VN-verdrag Handicap: Inclusief Onderwijs, § 40; V. Della Fina, 'Article 24 [Education]', in: V. Della Fina, R. Cera en G. Palmisano, The United Nations Convention on the Rights of Persons with Disabilities, Cham: Springer International Publishing 2017, p. 459.

3. Bijvoorbeeld G. de Beco, S. Quinlivan en J. Lord, The Right to Inclusive Education in International Human Rights Law, Cambridge: Cambridge University Press 2019

4. Bijvoorbeeld: $X$, 'Grote problemen over passend onderwijs', Zorgkrant 2018, https://zorgkrant.nl/jeugdzorg/8879-grote-problemen-overpassend-onderwijs; $X$, 'Leraren kampen met grote problemen door passend onderwijs', NOS 2019, https://nos.nl/artikel/2289573-lerarenkampen-met-grote-problemen-door-passend-onderwijs.html.

5. A. Dujardin, 'Boze ouders willen bij inspectie passend onderwijs afdwingen', Trouw 2020, https://www.trouw.nl/onderwijs/boze-ouderswillen-bij-inspectie-passend-onderwijs-afdwingen b02f3058f/? referer=https $\% 3 \mathrm{~A} \% 2 \mathrm{~F} \% 2 \mathrm{Fwww}$.google.com $\% 2 \mathrm{~F}$; voor een bespreking van de Belgische rechtszaken tot nu toe, zie bijvoorbeeld $M$. Spinoy en $K$. Willems, "Het $M$-decreet. " $M$ " voor méér of minder buitengewoon onderwijs?', TORB 2019, p. 94-96. Zie ook ruimer over de juridisering van het onderwijs: K. Willems, 'Individualisering van onderwijs en de gevolgen voor juridisering en rechtsbescherming', Nederlands Tijdschrift voor Onderwijsrecht en Onderwijsbeleid 2019, p. 39-45. 
vant te weten welke inspanning internationaalrechtelijk van landen verwacht wordt. Niet enkel de VN-rechtsorde verdient daarbij aandacht, ook het Europees Hof voor de Rechten van de Mens in Straatsburg (hierna: EHRM) buigt zich over een stijgend aantal zaken betreffende inclusief onderwijs. Het juridische aanknopingspunt daar is artikel 2 Eerste Protocol bij het Europees Verdrag voor de Rechten van de Mens (hierna: EP EVRM). Dit bevat het recht op onderwijs dat net zoals de andere verdragsrechten zonder discriminatie (bijv. op grond van handicap) verzekerd moet worden (cf. art. 14 EVRM).

2. In deze bijdrage wordt stilgestaan bij de recente uitspraak van het EHRM in Stoian t. Roemenië. ${ }^{6}$ Dit arrest is niet vrij van kritiek. ${ }^{7}$ In een gezamenlijk statement verweten meerdere organisaties die opkomen voor de rechten van personen met een handicap het Hof hun rechten niet afdoende te beschermen en de internationale standaarden ter zake, in de eerste plaats het $\mathrm{VN}$-verdrag Handicap, niet te respecteren. ${ }^{8}$ Hoe gegrond is deze kritiek?

Hierna bespreken we achtereenvolgens het arrest zelf, de verhouding van het arrest ten opzichte van eerdere rechtspraak van het $\mathrm{EHRM}^{9}$ en de plaats van het VN-verdrag Handicap in de Straatsburgse jurisprudentie. Vervolgens staan we stil bij twee belangrijke verplichtingen waarin het VN-verdrag Handicap voorziet inzake onderwijs: het VN-verdrag Handicap verplicht lidstaten enerzijds om hun onderwijssysteem voldoende toegankelijk te maken voor leerlingen met een handicap ('systeemtoegankelijkheid') en anderzijds om leerlingen redelijke aanpassingen te garanderen. Tot slot onderwerpen we de analyse van beide verplichtingen in Stoian $t$. Roemenië aan een kritische bespreking. Een belangrijke vaststelling daarbij is dat het EHRM met Stoian (opnieuw) weinig houvast biedt om de uitkomst van toekomstige zaken te voorspellen, en dus ook de concrete verplichtingen waar de Straatsburgse rechters nationale overheden aan zullen houden.

\section{Feiten en arrest}

3. De eisers in de zaak waren een jongen met spastische quadriplegie en zijn alleenstaande moeder.

6. EHRM 25 juni 2019, 289/14 (Stoian/Roemenië).

7. Zie bijv. C. Cojocariu, 'Stoian v. Romania: the Court's drift on disability rights intensifies', Strasbourg Observers 2019, https:// strasbourgobservers.com/2019/09/05/stoian-v-romania-the-courtsdrift-on-disability-rights-intensifies/.

8. 'Legal Action: European Court of Human Rights Fails Students With Disabilities', European Disability Forum 9 July 2019, http://www.edffeph.org/newsroom/news/european-court-human-rights-failsstudents-disabilities.

9. De focus van deze bijdrage ligt op de zaken betreffende onderwijs voor kinderen/studenten met een handicap. In de mate dat sommige kritieken op het Hof de bredere visie van het Hof op de rechten van mensen betreffen, wordt daar in deze bijdrage niet verder op ingegaan.
Door zijn aandoening was de jongen fysiek beperkt en had hij behoefte aan een rolstoel en andere assistentiemiddelen. ${ }^{10} \mathrm{Hij}$ had geen verstandelijke beperkingen en werd op overheidsadvies ingeschreven op een reguliere school. ${ }^{11}$ Tussen 2004 en 2017 ging de jongen naar meerdere scholen die volgens de eisers niet voldeden. Hun klacht behelsde meerdere aspecten van het onderwijs in twee van deze scholen. Ten eerste was er volgens hen een probleem met de toegankelijkheid, variërend van ontoegankelijke toiletten en leslokalen tot de onaangepastheid van de sportvoorzieningen. ${ }^{12}$ Dit zou de moeder van de jongen genoodzaakt hebben tot aanzienlijke kosten en inspanningen om deze gebreken te ondervangen. ${ }^{13}$ De overheid stelde daarentegen dat wel degelijk stappen waren gezet om aan deze behoeften tegemoet te komen en de toegankelijkheid in beide scholen te verhogen. ${ }^{14}$ Bovendien was volgens de overheid de situatie bemoeilijkt door de houding van de moeder die meerdere voorgestelde aanpassingen weigerde en niet steeds correct communiceerde over de noden van haar zoon. ${ }^{15}$ Verschillende andere vormen van ondersteuning zouden door de moeder bemoeilijkt zijn. ${ }^{16}$

4. De moeder diende meermaals klachten in wegens het gebrek aan ondersteuning voor haar zoon. ${ }^{17}$ In een eerste zaak werd door de Roemeense rechterlijke instanties geoordeeld dat de autoriteiten meerdere specifieke aanpassingen moesten doorvoeren (of blijven toepassen) om de jongen volwaardig toegang te waarborgen tot het reguliere onderwijs. ${ }^{18} \mathrm{De}$ eisers kregen echter ongelijk waar ze de terugbetaling van transportkosten van en naar de school vroegen, aangezien ze daarvoor reeds een jaarlijkse forfaitaire som kregen. ${ }^{19}$ In meerdere daaropvolgende beslissingen bevolen de rechters in kwestie de nationale autoriteiten op correcte wijze uitvoering te geven aan de eisen die uit deze eerste beslissing voortvloeiden. ${ }^{20}$ Volgens de eisers maakte hun behandeling door de nationale autoriteiten een schending uit van artikel 8 EVRM (het recht op privéleven, inclusief het recht op persoonlijke autonomie) en van artikel 2 EP EVRM, al dan niet in

10. EHRM 25 juni 2019, 289/14 (Stoian/Roemenië), § 10-11.

11. EHRM 25 juni 2019, 289/14 (Stoian/Roemenië), § 13 en 15

12. EHRM 25 juni 2019, 289/14 (Stoian/Roemenië), § 16-23.

13. Niet alleen zou ze zelf geïnvesteerd hebben in infrastructuuraanpassingen, ze zou de jongen ook naar de lokalen gedragen hebben. EHRM 25 juni 2019, 289/14 (Stoian/Roemenië), §17-18 \& 22

14. EHRM 25 juni 2019, 289/14 (Stoian/Roemenië), § 24-28 en 30-33.

15. EHRM 25 juni 2019, 289/14 (Stoian/Roemenië), § 29 en 33-34. Zie ook op § 69-70 over het 'incident' op 3 april 2013 waar de moeder van de jongen bij een ruzie met diens leerkracht onder dwang door de politie uit de school verwijderd werd. De dwang uitgeoefend door de politie werd later door een rechter proportioneel bevonden. Volgens de eisers vormde dit een schending van art. 3 en art. 8 EVRM, een bewering die volgens het Hof onvoldoende gestaafd werd (§ 112-116).

16. EHRM 25 juni 2019, 289/14 (Stoian/Roemenië), § 35-54.

17. EHRM 25 juni 2019, 289/14 (Stoian/Roemenië), § 55.

18. EHRM 25 juni 2019, 289/14 (Stoian/Roemenië), § 56-60.

19. EHRM 25 juni 2019, 289/14 (Stoian/Roemenië), § 59. Zie ook over het beroep daartegen: § 61-62.

20. EHRM 25 juni 2019, 289/14 (Stoian/Roemenië), § 63-68. 
samenhang gelezen met artikel 14 EVRM. ${ }^{21}$ De beweringen van de eisers werden ondersteund door verschillende tussenkomende partijen, onder meer de Speciale Rapporteur voor de Rechten van Personen met een Handicap van de Verenigde Naties en de Commissaris voor de Rechten van de Mens voor de Raad van Europa (hierna: Mensenrechtencommissaris). ${ }^{22}$

5. Het EHRM oordeelde vooreerst dat de Roemeense nationale rechters de klachten afdoende en uitgebreid hadden behandeld. ${ }^{23}$ Het erkende dat de procedure lang had angesleept, maar wees dit deels toe aan procedurele fouten van de eisers zelf. ${ }^{24}$ Bovendien hadden de nationale rechters telkens verzekerd dat afdoende ondersteuning verleend werd aan de jongen. ${ }^{25}$ Het EHRM stelde vast dat de autoriteiten aanraadden de jongen in het gewoon onderwijs school te laten lopen. Daarmee werd gehandeld in overeenstemming met de internationale standaard, namelijk inclusief onderwijs voor kinderen met een handicap. ${ }^{26}$ Inclusief onderwijs, zo onderstreepte het Hof, is het meest gepaste middel om inclusie en non-discriminatie in het onderwijs te verzekeren. ${ }^{27}$

6. Het Hof overwoog verder dat de Roemeense overheid toegaf dat het verzekeren van toegankelijkheid tot het algemeen onderwijssysteem slechts vertraagd plaatsvond. ${ }^{28}$ Waar de fysieke toegankelijkheid van het onderwijssysteem ontbreekt, moeten nationale overheden redelijke aanpassingen voorzien vanaf het moment dat deze worden gevraagd. ${ }^{29}$ Dergelijke redelijke anpassingen kunnen dan een tijdelijke oplossing vormen voor het gebrek aan toegankelijkheid. ${ }^{30}$ Tegelijkertijd mogen deze aanpassingen geen onevenredige belasting vormen voor de overheid. ${ }^{31}$ De aanpassingen kunnen op veel manieren worden ingevuld. ${ }^{32}$ De nationale autoriteiten zijn beter geplaatst dan het EHRM om hierover te beslissen. ${ }^{33}$ Wel moeten zij hierbij een bijzondere voorzichtigheid aan de dag leggen, gezien de impact van de gemaakte keuzes op een kwetsbare groep, namelijk kinderen met een handicap. ${ }^{34}$

21. EHRM 25 juni 2019, 289/14 (Stoian/Roemenië), § 73. Volgens de Roemeense autoriteiten waren de interne rechtsmiddelen overigens niet uitgeput. Omdat dit gelinkt werd aan de effectiviteit van het rechtssysteem en dus aan de grond van de zaak, ging het Hof hier niet afzonderlijk op in. Zie § 75-79.

22. EHRM 25 juni 2019, 289/14 (Stoian/Roemenië), § 5 en 89. Zie ook $\S 89-95$.

23. EHRM 25 juni 2019, 289/14 (Stoian/Roemenië), § 99.

24. EHRM 25 juni 2019, 289/14 (Stoian/Roemenië), § 100.

25. EHRM 25 juni 2019, 289/14 (Stoian/Roemenië), § 100.

26. EHRM 25 juni 2019, 289/14 (Stoian/Roemenië), § 101, met verwijzing naar Çam, § 64 en Enver Şahin, § 62

27. EHRM 25 juni 2019, 289/14 (Stoian/Roemenië), § 102.

28. lets wat ook de derde partijen in hun stukken aangeven. EHRM 25 juni 2019, 289/14 (Stoian/Roemenië), § 102

29. EHRM 25 juni 2019, 289/14 (Stoian/Roemenië), § 102.

30. EHRM 25 juni 2019, 289/14 (Stoian/Roemenië), § 103.

31. EHRM 25 juni 2019, 289/14 (Stoian/Roemenië), § 102.

32. EHRM 25 juni 2019, 289/14 (Stoian/Roemenië), § 102-103.

33. EHRM 25 juni 2019, 289/14 (Stoian/Roemenië), § 102-103 \& 109.

34. EHRM 25 juni 2019, 289/14 (Stoian/Roemenië), § 109.
7. Verder was het voor het EHRM relevant dat de jongen steeds een vorm van onderwijs genoot en daarin ook voortgang maakte. ${ }^{35}$ Ook toonden de autoriteiten zich bewust van hun verplichtingen betreffende toegang tot onderwijs en bleven de nationale rechters uitvoering van deze verplichtingen garanderen. ${ }^{36}$ Ten slotte bemoeilijkten de eisers zelf de uitvoering van meerdere redelijke aanpassingen. ${ }^{37} \mathrm{De}$ autoriteiten hielden rekening met de noden van de eiser, voorzagen daar financiering voor en voerden meerdere aanpassingen door (onder meer om de school rolstoeltoegankelijk te maken). ${ }^{38}$ Het Hof concludeerde dat er geen sprake was van een schending van artikel 8 EVRM, noch van artikel 2 EP EVRM, alleen of in samenhang gelezen met artikel 14 EVRM. $^{39}$

\section{Straatsburg en onderwijs voor kinderen met een beperking}

8. Stoian t. Roemenië was niet de eerste zaak waarin het EHRM zich diende uit te spreken over het recht op onderwijs voor kinderen met een handicap. ${ }^{40} \mathrm{Uit}$ voorafgaande zaken was onduidelijkheid ontstaan over de Straatsburgse kijk op deze materie. In de allereerste zaken aanvaardde het Hof dat kinderen met een handicap slechts minimale ondersteuning kregen in gewoon onderwijs en doorverwezen werden naar afzonderlijke instellingen. ${ }^{41}$ In latere uitspraken leek het EHRM de lat voor de lidstaten hoger te leggen. Zo veroordeelde het Hof Turkije in 2016 voor de weigering van een blinde studente aan de Turkish National Music Academy. ${ }^{42}$ Het Hof oordeelde dat de studente redelijke aanpassingen had moeten krijgen en enkel op grond van haar handicap (discriminerend) de toegang tot de universiteit was geweigerd. ${ }^{43}$ In 2018 veroordeelde het Hof Turkije opnieuw. ${ }^{44}$ Ditmaal voor het niet fysiek toegankelijk maken van een universiteit in hetzelfde jaar waarin deze aanpassing was gevraagd. Andere door de universiteit voorgestelde aanpassingen werden niet toereikend geacht. ${ }^{45}$ In deze twee arresten benadrukte het Hof de prioriteit van inclusief$$
\begin{aligned}
& \text { J. Lord, The Right to Inclusive Education in International Human } \\
& \text { Law, Cambridge: Cambridge University Press 2019, p. 424-446. } \\
& \text { Zie bijv. EHRM, Guide on Article } 2 \text { of Protocol No. } 1 \text { - Right to }
\end{aligned}
$$$$
\begin{aligned}
& \text { Zie bijv. EHRM } \\
& \text { tion, } \$ 47-48 \text {. }
\end{aligned}
$$

42. EHRM 23 februari 2016, 51500/08 (Çam/Turkije).

43. EHRM 23 februari 2016, 51500/08 (Çam/Turkije), § 65-69.

44. EHRM 30 januari 2018, 23065/12 (Enver Şahin/Turkije).

45. EHRM 30 januari 2018, 23065/12 (Enver Şahin/Turkije), § 62-65. 
onderwijs, steunend op de internationale consensus zoals weerspiegeld in het VN-verdrag Handicap. ${ }^{46}$

9. Deze prioriteit blijkt veel minder sterk uit een recentere beslissing in een zaak tegen Frankrijk (uitgesproken door een comité van drie rechters). In Dupin t. Frankrijk beschouwde het Hof de gedwongen doorverwijzing naar een gespecialiseerde instelling van een jongen met een autismespectrumstoornis niet als problematisch. ${ }^{47}$ De rechters vermeldden het VN-verdrag Handicap niet eens in hun beslissing en concludeerden na een summiere toetsing dat Frankrijk genoeg deed om het recht op onderwijs voor kinderen met een handicap te verzekeren. De toetsingsintensiteit leek dan ook te verschillen van de voorgaande zaken en de vraag rees - onder meer door de afwezigheid van het $\mathrm{VN}$-verdrag Handicap - of het Hof de lat opnieuw lager legde inzake inclusief onderwijs. Van de zaak Stoian werd gehoopt dat die duidelijkheid zou brengen. Hieronder wordt eerst ingegaan op de plaats van het VN-verdrag Handicap in deze beslissing. Vervolgens wordt de toetsingsstandaard zoals die blijkt uit Stoian geanalyseerd voor de twee relevante verplichtingen inzake inclusief onderwijs, namelijk de systeemtoegankelijkheid en de redelijke aanpassingsplicht.

\section{Artikel $24 \mathrm{VN}$-verdrag Handicap als relevante standaard voor het EVRM?}

10. In zijn beslissingen en arresten verwijst het EHRM ook naar de relevante internationaalrechtelijke verplichtingen in een bepaalde materie. Die internationaalrechtelijke verplichtingen, zeker wanneer de verdragen in kwestie door veel staten geratificeerd werden, kunnen dienen als indicatie voor de Europese consensus over zich ontwikkelende zaken. ${ }^{48}$ Het Hof neemt deze consensus in aanmerking bij de interpretatie van een verdragsverplichting. ${ }^{49}$ De consensus leidt doorgaans tot een strengere toetsingsintensiteit en een kleinere margin of appreciation voor de betrokken staat. ${ }^{50}$ Het lijkt niet onterecht

EHRM 23 februari 2016, 51500/08 (Çam/Turkije), § 53 en 63-64; EHRM 30 januari 2018, 23065/12 (Enver Şahin/Turkije), § 53, 55 en 63.

47. EHRM 18 december 2018, 2282/17 (Dupin/Frankrijk, beslissing). Voor een uitgebreidere bespreking, zie bijvoorbeeld J. Lievens en M. Spinoy, 'Leerlingen met specifieke onderwijsbehoeften in Straatsburg. Maakt inclusief onderwijs school?', Nieuw Juridisch Weekblad 2019, p. 778.

48. Bijvoorbeeld: EHRM 30 januari 2018, 23065/12 (Enver Şahin/Turkije), § 55; W. Schabas, p. 47-48.

49. Zie bijvoorbeeld: L. Helfer, 'Consensus, Coherence and the European Convention on Human Rights', Cornell International Law Journal 1993, p. 138; Raad van Europa, 'Interpretive mechanisms of ECHR case-law: the concept of European consensus', https://www.coe.int/en/web/ help/article-echr-case-law.

50. L. Helfer, 'Consensus, Coherence and the European Convention on Human Rights', Cornell International Law Journal 1993, p. 136-138; dat het Hof het VN-verdrag Handicap (waarbij intussen 181 staten partij zijn ${ }^{51}$ ) meeneemt in zijn interpretatie van het recht op onderwijs. De brede gedragenheid van de principes uit het $\mathrm{VN}$-verdrag Handicap leidt dan tot een VN-verdrag Handicapconforme interpretatie van de relevante EVRM-verplichtingen.

11. Zowel in Çam als in Enver Şahin, de twee hoger vermelde zaken tegen Turkije, werd onder verwijzing naar onder meer het $\mathrm{VN}$-verdrag Handicap gesteld dat inclusief onderwijs het belangrijkste middel vormt om universaliteit en non-discriminatie in het onderwijs te verzekeren. ${ }^{52}$ Ook werden de bepalingen uit het EVRM expliciet in overeenstemming met het VN-verdrag Handicap geïnterpreteerd. ${ }^{53}$ Dit is niet verwonderlijk aangezien het VN-verdrag Handicap algemeen beschouwd wordt als 'the international benchmark and legal reference point in all matters pertaining to disability'. ${ }^{5}$ Artikel $24 \mathrm{VN}$ verdrag Handicap is bij uitstek relevant, aangezien daarin het recht op onderwijs voor kinderen met een handicap is verankerd.

12. Nadat het Hof in Dupin t. Frankrijk het VN-verdrag Handicap onverwacht (en onbegrijpelijk) volledig buiten beschouwing liet, grijpt het in Stoian terug naar zijn redenering in Çam en Enver Şahin. Via verwijzing naar Çam en andere rechtspraak verwijst het EHRM naar het VN-verdrag Handicap als onderdeel van het relevant internationaal recht. ${ }^{55}$ Ook in het beschikkend gedeelte van het arrest wordt het IVRPH indirect genoemd: opnieuw verwijzend naar Çam (waar het VN-verdrag Handicap expliciet wordt genoemd) oordeelt het Hof dat inclusief onderwijs naar internationale standaarden het meest gepaste middel vormt voor het garanderen van inclusie en non-discriminatie op vlak van onderwijs. ${ }^{56}$ Hoewel het EHRM de principes van het VN-verdrag Handicap dus volgt, verwijst het er niet langer expliciet naar. Bovendien blijven er in de toepassing van deze principes discrepanties bestaan tussen het EVRM (zoals toegepast door het Hof) en het $\mathrm{VN}$-verdrag Handicap.

Raad van Europa, 'Interpretive mechanisms of ECHR case-law: the concept of European consensus', https://www.coe.int/en/web/help/ article-echr-case-law.

51. Zie: https://www.un.org/development/desa/disabilities/convention-onthe-rights-of-persons-with-disabilities.html.

52. EHRM 23 februari 2016, 51500/08 (Çam/Turkije), § 37-38 en 64; EHRM 30 januari 2018, 23065/12 (Enver Şahin/Turkije), § 19 en 55.

53. EHRM 23 februari 2016, 51500/08 (Çam/Turkije), § 65; EHRM 30 januari 2018, 23065/12 (Enver Şahin/Turkije), § 53 en 60.

54. Mensenrechtencommissaris, Third Party Intervention by the Council of Europe Commissioner for Human Rights in Stoian v. Romania, § 25. Zie ook: T. Degener en A. Begg, 'From Invisible Citizens to Agents of Change: A Short History of the Struggle for the Recognition of the Rights of Persons with Disabilities at the United Nations', in: V. Della Fina, R. Cera en G. Palmisano, The United Nations Convention on the Rights of Persons with Disabilities, Cham: Springer International Publishing 2017, p. 37-38.

55. EHRM 25 juni 2019, 289/14 (Stoian/Roemenië), § 72.

56. EHRM 25 juni 2019, 289/14 (Stoian/Roemenië), § 101. 
13. Zo heeft het EHRM het over de doelstelling van inclusief onderwijs als 'the integration of children with a disability in mainstream schools' terwijl integratie onder het $\mathrm{VN}$-verdrag Handicap nadrukkelijk een eigen, van inclusie afwijkende betekenis heeft. ${ }^{57}$ Integratie betekent dat kinderen met een handicap in het algemeen onderwijs mogen meedoen mits zij beantwoorden aan de standaardeisen die daar gesteld worden. ${ }^{58}$ De 'aanpassingskosten' liggen hier bij de leerling. Inclusie vereist daarentegen dat bestaande drempels in het systeem voor kinderen met een beperking weggenomen worden. ${ }^{59}$ Het vereist aangepaste lesinhoud, lesmethoden, onderwijsstructuren en -strategieën opdat zoveel mogelijk leerlingen met verschillende noden deel kunnen uitmaken van het onderwijssysteem. ${ }^{60}$ De 'aanpassingskost' wordt daarbij gedragen door het systeem. De verplichtingen die op staten rusten zijn dus groter bij inclusie dan bij integratie. Voor het IVRPH - daarin bijgetreden door de Mensenrechtencommissaris - voldoet enkel een inclusief onderwijssysteem. ${ }^{61}$ De verwijzing van het EHRM naar integratie als einddoelstelling van inclusief onderwijs is minstens verwarrend en verraadt in het slechtste geval een gebrekkig begrip van de relevante standaarden. Ook bij het verschil tussen de toegankelijkheidsverplichting en de verplichting tot redelijke aanpassing lijkt het Hof af te wijken van het $\mathrm{VN}$ verdrag Handicap. Daarop gaan we hieronder in.
57. EHRM 25 juni 2019, 289/14 (Stoian/Roemenië), § 102. wijs, § 11; M. Jones, 'Inclusion, social inclusion and participation', in: L. Basser, M. Jones en M. Rioux, Critical Perspectives on human rights and disability law, Leiden: Martinus Nijhoff 2011, 63; A. D'Espallier, Tijdschrift voor Jeugd en Kinderrechten 2018, 316. Dit is overigens de huidige standaard in het Nederlandse 'passend onderwijs'. Zie J. Wevers, 'Wij zullen segregatie in het onderwijs steeds minder gaan accepteren', Balans, https://balansdigitaal.nl/nieuws/zullen-segregatieonderwijs-steeds-minder-gaan-accepteren/.

59. General Comment no. 4 bij het VN-verdrag Handicap: Inclusief Onderwijs, § 11; M. Jones, Inclusion, social inclusion and participation, in: L. Basser, M. Jones en M. Rioux, Critical Perspectives on human rights and disability law, Leiden: Martinus Nijhoff 2011, 63; A. D'Espallier, Tijdschrift voor Jeugd en Kinderrechten 2018, 316.

60. General Comment no. 4 bij het VN-verdrag Handicap: Inclusief Onderwijs, § 11.

61. General Comment no. 4 bij het VN-verdrag Handicap: Inclusief Onderwijs, § 8 en 11; Mensenrechtencommissaris, Third Party Intervention by the Council of Europe Commissioner for Human Rights in Stoian v. Romania, § 9 en 32

\section{Systeemtoegankelijkheid en redelijke aanpassingen: verschillende verplichtingen met verschillende toetsingsstandaarden?}

14. Een van de kritieken van ngo's op de uitspraak in Stoian t. Roemenië is dat het EHRM toegankelijkheid en redelijke aanpassingen niet correct heeft onderscheiden. ${ }^{62}$ Gelijkaardige kritiek was al te lezen in de dissenting opinion van rechter Lemmens bij Enver Şahin t. Turkije (2018). Hij wees erop dat de toegankelijkheid van het onderwijssysteem onder artikel 2 EP EVRM beoordeeld moet worden, terwijl redelijke aanpassingen - als deel van de nondiscriminatieverplichtingen - vallen onder artikel 2 EP EVRM in samenhang met artikel $14 E V R M^{63} \mathrm{Hij}$ steunde zijn redenering op het $\mathrm{VN}$-verdrag Handicap en de General Comments daarbij. ${ }^{64}$ Het VNverdrag Handicap omvat inderdaad zowel de verplichting tot systeemtoegankelijkheid als de verplichting om redelijke aanpassingen te garanderen en verschillende General Comments benadrukken dat deze verplichtingen niet hetzelfde inhouden. ${ }^{65}$ Uit de samenlezing van het $\mathrm{VN}$-verdrag Handicap en de General Comments kunnen we het volgende afleiden. ${ }^{66}$

15. Conceptueel ligt het grootste onderscheid wellicht in de context waarin en het moment waarop de twee verplichtingen worden toegepast. Artikel $24 \mathrm{VN}$ verdrag Handicap vereist dat staten een inclusief onderwijssysteem voorzien. Deze verplichting houdt onder meer in dat staten hun onderwijssysteem toegankelijk maken ${ }^{67}$ Deze systeemtoegankelijkheid vergt reflectie over de inrichting van het systeem los van specifieke vragen om een bepaalde school toegankelijk te maken voor een individueel kind. ${ }^{68}$ Staten moeten structurele drempels in hun

62. 'Legal Action: European Court of Human Rights Fails Students With Disabilities', European Disability Forum 9 July 2019, http://www.edffeph.org/newsroom/news/european-court-human-rights-failsstudents-disabilities.

63. Dissenting opinion rechter Lemmens bij EHRM 30 januari 2018, 23065/12 (Enver Şahin/Turkije), § 2-3.

64. Dissenting opinion rechter Lemmens bij EHRM 30 januari 2018, 23065/12 (Enver Şahin/Turkije), § 4-5. Dergelijke General Comments gaan uit van het VN-Comité voor de Rechten van Personen met een Handicap. Zij vormen een gezaghebbende bron bij de interpretatie van het VN-verdrag Handicap. M. Spinoy en K. Willems, 'Het M-decreet. " $M$ " voor méér of minder buitengewoon onderwijs?', TORB 2019, p. 76-79.

65. Zie ook art. 5, 9 en 24 VN-verdrag Handicap.

66. Een uitgebreidere bespreking van deze verplichtingen is te vinden in $M$. Spinoy en $\mathrm{K}$. Willems, 'Het $M$-decreet. " $M$ " voor méér of minder buitengewoon onderwijs?', TORB 2019, p. 72-75.

67. General Comment no. 4 bij het VN-verdrag Handicap: Inclusief Onderwijs, § 49 over het verband tussen inclusief onderwijs en systeemtoegankelijkheid. Zie ook $\S 22$ van diezelfde General Comment.

68. General Comment no. 2 bij het VN-verdrag Handicap: Toegankelijkheid, § 25; General Comment no. 4 bij het VN-verdrag Handicap: Inclu- 
onderwijssysteem voor kinderen met een beperking identificeren en wegnemen. ${ }^{69}$ De noden van verschillende groepen moeten deel uitmaken van de inrichting van het systeem, bijvoorbeeld door de invoering van algemene toegankelijkheidsstandaarden. ${ }^{70}$ Deze wijzigingen worden dus op groepsniveau getroffen. ${ }^{71}$ Ook artikel 2 EP EVRM omvat positieve verplichtingen voor staten om de toegang tot bestaande onderwijsinstellingen te verzekeren. ${ }^{72}$ Volgens rechter Lemmens is het ook hieronder dat de systeemtoegankelijkheid te situeren valt. ${ }^{73}$

16. De verplichting in redelijke aanpassingen te voorzien, speelt daarentegen in een bepaalde school nadat daar een individuele aanpassing gevraagd wordt door (de ouders van) een kind met een handicap. ${ }^{74}$ Ook in een aangepast systeem kunnen redelijke aanpassingen nodig blijven, bijvoorbeeld voor kinderen met heel specifieke ondersteuningsnoden of een zeldzame aandoening. ${ }^{75}$ Tegenover deze plicht staat een individueel recht op redelijke aanpassingen dat deel uitmaakt van het recht op gelijke behandeling. ${ }^{76}$ De verplichting wordt ingevuld vanuit een evaluatie van de noden van de leerling in de concrete schoolsituatie. ${ }^{77}$

17. Praktisch ligt het voornaamste verschil bij de doorwerking van deze verplichtingen. Als deel van de non-discriminatieplicht moeten redelijke aanpassingen waar gevraagd onmiddellijk gerealiseerd worden. ${ }^{78}$ Als verplichting met directe werking kan die door leerlingen voor de rechter opgeëist worden.

sief Onderwijs, § 29; General Comment no. 6 bij het VN-verdrag Handicap: Gelijkheid en Non-Discriminatie, § 24a.

69. General Comment no. 2 bij het VN-verdrag Handicap: Toegankelijkheid, § 25; General Comment no. 4 bij het VN-verdrag Handicap: Inclusief Onderwijs, § 29.

70. General Comment no. 2 bij het VN-verdrag Handicap: Toegankelijkheid, § 25; General Comment no. 6 bij het VN-verdrag Handicap: Gelijkheid en Non-Discriminatie, § 24a.

71. General Comment no. 2 bij het VN-verdrag Handicap: Toegankelijkheid, § 25; General Comment no. 4 bij het VN-verdrag Handicap: Inclusief Onderwijs, § 29.

72. EHRM, Guide on Article 2 of Protocol No. 1-Right to Education, § 3-4.

73. Dissenting opinion rechter Lemmens bij EHRM 30 januari 2018, 23065/12 (Enver Şahin/Turkije), § 2-3. Het Hof leest de verplichtingen onder art. 2 EP EVRM ook in samenhang met onder meer het VN-verdrag Handicap. EHRM, Guide on Article 2 of Protocol No. 1-Right to Education, § 10.

74. General Comment no. 2 bij het VN-verdrag Handicap: Toegankelijkheid, § 26; General Comment no. 6 bij het VN-verdrag Handicap: Gelijkheid en Non-Discriminatie, § $24 \mathrm{~b}$.

75. General Comment no. 2 bij het VN-verdrag Handicap: Toegankelijkheid, § 25-26; General Comment no. 4 bij het VN-verdrag Handicap: Inclusief Onderwijs, § 29.

76. Art. 5 lid $3 \mathrm{VN}$-verdrag Handicap; J. Lord en R. Brown, 'The role of reasonable accommodation in securing substantive equality for persons with disabilities: the UN Convention on the Rights of Persons with Disabilities', in: L. Basser, M. Jones en M. Rioux, Critical Perspectives on human rights and disability law, Leiden: Martinus Nijhoff 2011, p. 276-281.

77. General Comment no. 2 bij het VN-verdrag Handicap: Toegankelijkheid, § 26; General Comment no. 4 bij het VN-verdrag Handicap: Inclusief Onderwijs, § 30 .

78. General Comment no. 4 bij het VN-verdrag Handicap: Inclusief Onderwijs, § 28, 31 en 41b; General Comment no. 6 bij het VN-verdrag Handicap: Gelijkheid en Non-Discriminatie, § 12, 18c en 23. Zie ook art. 5 lid 3 VN-verdrag Handicap.
De plicht tot het verzekeren van een toegankelijk onderwijssysteem moet daarentegen slechts gradueel geimplementeerd worden. ${ }^{79}$ Hoewel staten wel een stappenplan met concrete doelstellingen en een tijdsbestek voor de realisatie moeten opstellen, wordt niet vereist dat het volledige onderwijssysteem van de ene dag op de andere volledig toegankelijk gemaakt wordt. ${ }^{80}$

18. Dit verschil heeft ook implicaties voor de standaarden waaraan staten onder deze twee verplichtingen gehouden worden. Een redelijke aanpassing kan immers geweigerd worden wanneer de verplichting aantoonbaar niet redelijk is of een onevenredige belasting vormt voor de actor van wie deze gevraagd wordt (onder meer gelet op de financiële en organisatorische belasting van de aanpassing). ${ }^{81} \mathrm{De}$ systeemaanpassing kan wel gradueel gerealiseerd worden, maar staten kunnen zich hierbij niet beroepen op overmacht met betrekking tot de kostprijs. ${ }^{82}$

19. Deze verschillen nemen niet weg dat in de praktijk een maatregel die als redelijke aanpassing gevraagd wordt ten aanzien van een specifieke leerling ook voor andere leerlingen de toegankelijkheid kan verhogen. ${ }^{83}$ Wanneer bijvoorbeeld om de toegankelijkheid van een individuele leerling te faciliteren in een ontoegankelijk gebouw een lift wordt geïnstalleerd, vormt dit een redelijke aanpassing. Wordt diezelfde lift geinstalleerd los van een dergelijke individuele vraag, dan gaat het om een systeemaanpassing. Puur op grond van de inhoud van de maatregel kan dus niet vastgesteld worden of het om een redelijke aanpassing of systeemaanpassing gaat. In een onaangepast systeem kunnen individuele redelijke aanpassingen de kloof tussen de leerling met een beperking en het systeem overbruggen. ${ }^{84}$ Het feit dat deze aanpassingen een blijvend karakter kunnen hebben en dus ook andere leerlingen ten goede kunnen komen, verandert daar niets aan. Dit is ook de manier waarop het EHRM de redelijke aanpassingen in Çam en Enver Şahin leek te interpreteren. Terwijl de Turkse overheid de kostprijs van toegankelijkheid en de onaangepastheid van het systeem aanhaalde, antwoordde het Hof dat redelijke aanpassingen voor-

79. General Comment no. 2 bij het VN-verdrag Handicap: Toegankelijkheid, § 24 en 27; General Comment no. 4 bij het VN-verdrag Handicap: Inclusief Onderwijs, § 29. Nieuwe goederen en diensten moeten echter onmiddellijk toegankelijk ontworpen worden. General Comment no. 2 bij het VN-verdrag Handicap: Toegankelijkheid, § 15 en 24.

80. General Comment no. 2 bij het VN-verdrag Handicap: Toegankelijkheid, § 24 en 27; General Comment no. 4 bij het VN-verdrag Handicap: Inclusief Onderwijs, § 29, 40 en 64

81. General Comment no. 2 bij het VN-verdrag Handicap: Toegankelijkheid, § 25; General Comment no. 6 bij het VN-verdrag Handicap: Gelijkheid en Non-Discriminatie, § 25.

82. General Comment no. 2 bij het VN-verdrag Handicap: Toegankelijkheid, § 25 .

83. General Comment no. 6 bij het VN-verdrag Handicap: Gelijkheid en Non-Discriminatie, $\S 24 \mathrm{~b}$.

84. General Comment no. 6 bij het VN-verdrag Handicap: Gelijkheid en Non-Discriminatie, § 42 
zien moesten worden. ${ }^{85}$ In beide zaken was de Staat daarin tekortgeschoten. Dat redelijke aanpassingen een overbruggingsfunctie kunnen hebben - in afwachting van systeemhervormingen - werd door het EHRM pas in Stoian expliciet gemaakt: 'In the absence of accessibility of the physical environment prior to the integration of children with a disability in mainstream schools, the authorities have an obligation to provide reasonable accommodation...' 86

\section{Stoian t. Roemenië: is het EHRM wel bij de les?}

20. Toch roept de aanpak van het EHRM in Stoian ook vragen op aangaande de interpretatie en toepassing van de twee voornoemde verplichtingen. Ten eerste is het vreemd dat het Hof niet expliciet heeft onderzocht in welke mate Roemenië voldeed aan de (progressief te realiseren) toegankelijkheidsplicht. Zoals gezegd vormt het realiseren van de systeemtoegankelijkheid een verplichting onder artikel 2 EP EVRM. Zowel de eisers als verschillende tussenkomende partijen wezen op het gebrek aan toegankelijkheid van het Roemeense onderwijs. ${ }^{87} \mathrm{De}$ Roemeense autoriteiten gaven bovendien zelf toe slechts met vertraging vooruitgang te boeken op dat vlak. ${ }^{88}$ Het Hof nam hiervan wel akte, maar onderzocht vervolgens niet welke stappen Roemenië reeds had gezet en nog van plan was te zetten. ${ }^{89}$ In plaats van ten gronde te evalueren of Roemenië voldoet aan de plicht tot systeemtoegankelijkheid, verlegde het Hof de focus zonder meer naar redelijke aanpassingen.

Dit is des te merkwaardiger gezien de parallelle beslissingen van het Europees Comité voor de Sociale Rechten dat zich hierover wél al uitsprak ten aanzien van andere landen en aangaf dat staten wel degelijk stappen moeten zetten om te voldoen aan hun progressieve realisatieplicht op systeemniveau. ${ }^{90}$ Ook uit het IVRPH en de relevante General Comments kunnen minimumvereisten afgeleid worden. Het gaat dan om het opstellen van een stappenplan, te implementeren binnen een vastgesteld tijdsbestek, en het voorzien van voldoende

23 februari 2016, 51500/08 (Cam/Turkije), \$ 63-65: EHRM 30 januari 2018, 23065/12 (Enver Şahin/Turkije), § 57-60

86. EHRM 25 juni 2019, 289/14 (Stoian/Roemenië), § 102.

87. EHRM 25 juni 2019, 289/14 (Stoian/Roemenië), § 16-23 en 102.

88. EHRM 25 juni 2019, 289/14 (Stoian/Roemenië), § 102.

89. EHRM 25 juni 2019, 289/14 (Stoian/Roemenië), § 102.

90. Het gaat onder meer om de realisatie van het recht binnen een redelijk tijdsbestek via een stappenplan met duidelijk afgebakende doelen, met meetbare vooruitgang en gebruik van alle mogelijke middelen. Niet de wetgeving die het recht bevestigt, maar de implementatie daarvan is cruciaal. Staten moeten de implementatie bovendien opvolgen en evalueren. M. Spinoy en K. Willems, 'Het $M$-decreet. " $M$ " voor méér of minder buitengewoon onderwijs?', TORB 2019, p. 80-85. Zie ook Mensenrechtencommissaris, Third Party Intervention by the Council of Europe Commissioner for Human Rights in Stoian v. Romania, § 33 financiële middelen. ${ }^{91}$ Ook moeten staten duidelijk identificeren welke actor voor welke stap verantwoordelijk is en moeten ze toezicht op en naleving van deze stappen verzekeren. ${ }^{92}$ Of dezelfde minimumvereisten ook onder het EVRM gelden, blijft dus zeer de vraag. Het EHRM miste hier opnieuw ${ }^{93}$ een kans om verduidelijking te brengen.

21. Het EHRM verlegde de focus dus naar een onderzoek van de redelijke aanpassingen. Zoals in de eerdere zaken stelde het Hof dat de nationale autoriteiten in beginsel het best in staat zijn om over de (meest gepaste) redelijke aanpassing te oordelen (met bijzondere aandacht voor de kwetsbaarheid van de betrokken groep). ${ }^{94}$ Gelet op de feitelijke, individuele en contextuele aard van het onderzoek betreffende de redelijke anpassingen ${ }^{95}$ lijkt het logisch dat het Hof zich als supranationale instantie terughoudend opstelt bij de toetsing. Toch lijkt ook op dit punt de redenering in Stoian niet helemaal zuiver.

Ten eerste lijkt het EHRM in de beoordeling van de redelijkheid van de aanpassingen verschillende systeemfactoren mee te hebben genomen. Hoewel de systeemfactoren wellicht deel kunnen uitmaken van de contextuele afweging, moet het zwaartepunt van dit onderzoek toch liggen bij de individuele situatie van de betrokken leerling en de specifieke school. ${ }^{96}$ Het Hof richtte zich evenwel op de wetgeving, de houding van de nationale rechters (die het als betrouwbaar beoordeelden), het feit dat de Staat zich bewust was van de (inter)nationaalrechtelijke verplichting etc., ${ }^{97}$ allemaal factoren die eerder aansluiten bij de evaluatie van de andere verplichting onder het VN-verdrag Handicap om de toegankelijkheid tot het onderwijssysteem te waarborgen. Nog in zijn evaluatie van de redelijke aanpassingen sprak het Hof over de verplichting 'to allocate resources in order to meet the educational needs of

91. General Comment no. 2 bij het VN-verdrag Handicap: Toegankelijkheid, § 24; General Comment no. 4 bij het VN-verdrag Handicap: Inclusief Onderwijs, § 40 en 64

92. General Comment no. 2 bij het VN-verdrag Handicap: Toegankelijkheid, § 24.

93. Ook in Enver Şahin had het Hof dit onderscheid al duidelijk kunnen toepassen, aangezien de eiser zich zowel op art. 2 EP EVRM beriep als op art. 2 EP EVRM jo. art. 14 EVRM. In § 56 van deze zaak lijkt het Hof ook daar te stellen dat de systeemtoegankelijkheid problematisch is, zonder hier verdere gevolgen aan te verbinden. Zie ook de dissenting opinion van rechter Lemmens bij EHRM 30 januari 2018, 23065/12 (Enver Sahin/Turkije). In de eerdere zaak Ghergina t. Roemenië kwam de verhouding tussen redelijke aanpassingen en systeemtoegankelijkheid ook aan bod. De eiser stelde immers dat van individuele burgers niet verwacht mag worden dat zij openbare dienstverleners dagvaarden om toegang tot gebouwen te verkrijgen. Het Hof verwierp deze klacht echter wegens een gebrek aan uitputting van de interne rechtsmiddelen (EHRM 18 september 2015, 42219/07, (Ghergina/Roemenië), §114-116).

94. EHRM 25 juni 2019, 289/14 (Stoian/Roemenië), § 102 en 109

95. General Comment no. 4 bij het VN-verdrag Handicap: Inclusief Onderwijs, § 30 .

96. Het gaat voor het EHRM immers om de verplichting van staten de redelijke aanpassingen te garanderen, niet over het voorzien van de aanpassing zelf waarvoor doorgaans de school verantwoordelijk is.

97. EHRM 25 juni 2019, 289/14 (Stoian/Roemenië), § 99-101 en 103. 
children with disabilities'. ${ }^{98}$ Bovendien concludeerde het Hof dat er geen schending was van artikel 8 EVRM, of artikel 2 EP EVRM alleen of in samenhang gelezen met artikel 14 EVRM. ${ }^{99}$ Dat artikel 2 EP EVRM ook 'alleen' beoordeeld werd, is een bijkomende indicatie dat het Hof zich hier heeft laten verleiden onrechtstreeks alsnog aan beide verplichtingen te toetsen. Aldus zou dan blijken dat noch de systeemverplichting noch de verplichting redelijke aanpassingen te voorzien, geschonden is. Gezien de bovengenoemde verschillen tussen beide verplichtingen lijkt een dergelijke conclusie echter twee afzonderlijke, grondigere analyses te vereisen.

22. Daarnaast lijkt het EHRM de toetsingsintensiteit voor de verplichting tot redelijke aanpassingen te hebben afgezwakt in vergelijking met zijn uitspraak in Enver Şahin t. Turkije. Zo stelde het Hof goedkeurend vast dat de lift in een school dan wel niet in hetzelfde jaar geinstalleerd werd (wegens een gebrek een middelen), maar dat dit toch het daaropvolgende jaar gebeurde. ${ }^{100}$ In Enver Şahin leek de fysieke toegankelijkheid van de gebouwen in hetzelfde jaar maarin die gevraagd perd echter de enige voor het Hof aanvaardbare redelijke aanpassing. Het gebrek aan middelen op dat moment leek niet relevant. Ook werd in Stoian ten voordele van de Staat overwogen dat de tweede eiser zich niet erg constructief opstelde. ${ }^{101}$ In Enver Şahin besteedde enkel rechter Lemmens in zijn dissenting opinion aandacht aan de houding van de eiser. ${ }^{102}$ Door op beide punten een andere insteek te volgen, lijkt het Hof hier een stap teruggezet te hebben in het waarborgen van het recht op redelijke aanpassingen voor leerlingen met een handicap. Mogelijk wordt dit deels ondervangen door de grondrechtencontrole op nationaal niveau. In Stoian benadrukt het Hof immers dat de nationale rechters ervoor zorgden dat de autoriteiten hun verplichtingen nakwamen. ${ }^{103}$ In Enver Şahin hadden de nationale rechters dit volgens het Hof niet gedaan. ${ }^{104}$ Opnieuw lijkt de toetsingswijze echter te verschillen, aangezien in Enver Şahin de analyse van het rechterlijk handelen een afzonderlijk onderzoek uitmaakt, naast het gedrag van de relevante onderwijsactoren. Ze worden elk afzonderlijk geacht laakbare handelingen gesteld te hebben. ${ }^{105}$ In het gezamenlijk onderzoek van de twee soorten overheidsactoren in Stoian kan het diligent handelen van de rechters net een tegen-

EHRM 25 juni 2019, 289/14 (Stoian/Roemenië), § 110. Ook in § 109 wordt het verhogen van de toegankelijkheid onder de redelijke aanpassingen bekeken.

99. EHRM 25 juni 2019, 289/14 (Stoian/Roemenië), § 111.

100. EHRM 25 juni 2019, 289/14 (Stoian/Roemenië), § 33 en 108.

101. EHRM 25 juni 2019, 289/14 (Stoian/Roemenië), § 107-108

102. Dissenting opinion rechter Lemmens bij EHRM 30 januari 2018, 23065/12 (Enver Şahin/Turkije), \& 8 en 10-11.

103. EHRM 25 juni 2019, 289/14 (Stoian/Roemenië), § 99-100, 106-107 en 109.

104. EHRM 30 januari 2018, 23065/12 (Enver Şahin/Turkije), § 66-67.

105. EHRM 30 januari 2018, 23065/12 (Enver Şahin/Turkije), § 57-67. wicht bieden voor eventuele fouten van andere overheidsactoren.

23. Tot slot lijkt het Hof ook te hebben geïmpliceerd dat de plicht tot redelijke aanpassingen enkel in een volstrekt onaangepast schoolsysteem bestaat: het had het immers over de plicht tot redelijke aanpassingen als bestaande in the absence of accessibility'. ${ }^{106}$ Hierboven is al aangestipt dat ook in een toegankelijk systeem nog een nood kan bestaan aan redelijke aanpassingen, bijvoorbeeld voor iemand met erg specifieke ondersteuningsnoden of voor iemand met een zeldzame aandoening. De twee verplichtingen heffen elkaar niet op, maar zijn complementair in het verzekeren van inclusief onderwijs. Dit doet ook de vraag rijzen of de toetsingsstandaard voor een redelijke aanpassing in een toegankelijk systeem anders moet zijn dan de toetsingsstandaard voor een redelijke aanpassing die slechts als overbruggingsmaatregel geldt tot een betere toegankelijkheid op systeemniveau is gecreëerd. ${ }^{107} \mathrm{Bij}$ zo'n overbruggingsmaatregel geldt dat de Staat terzelfdertijd ook stappen moet zetten om het onderwijssysteem toegankelijker te maken. Als de toegankelijkheid evenwel niet afzonderlijk wordt onderzocht (zoals hier in Stoian) en lidstaten kunnen volstaan met (beperkte) redelijke aanpassingen, dan lijkt er (althans wat het EHRM betreft) weinig incentive voor staten om die toegankelijkheid ook op systeemniveau daadwerkelijk te realiseren.

\section{Conclusie}

24. Ook na Stoian blijft onduidelijk wat een staat naar Straatsburgse normen minimaal moet doen inzake onderwijs voor kinderen met een handicap. Enerzijds bevestigt het EHRM de principes uit de zaken Çam t. Turkije en Enver Şahin t. Turkije. Het VNverdrag Handicap vormt de relevante internationale standaard en inclusief onderwijs moet de prioriteit krijgen. Anderzijds lijkt het Hof ervoor terug te deinzen de mate waarin staten hun onderwijssysteem toegankelijk maken voor leerlingen met een handicap diepgaand te onderzoeken. Als Stoian een indicatie is voor toekomstige rechtspraak, kunnen staten veroordelingen door het EHRM vermijden door het ad hoc aanbieden van redelijke aanpassingen. Deze indruk wordt versterkt door de vermenging van de twee verplichtingen in het onderzoek naar de redelijke aanpassingen. Ook lijkt het Hof een lagere toetsingsintensiteit te hebben gehanteerd dan in deze eerdere zaken. Een belangrijk element is wel de vaststelling door het EHRM dat de nationale rechters reeds nauwgezet te werk zijn gegaan bij het beoordelen (en veroordelen) van de tekortkomingen van de Roemeense autoriteiten. Mogelijk zal het

106. EHRM 25 juni 2019, 289/14 (Stoian/Roemenië), § 102.

107. Vergelijk ook General Comment no. 4 bij het VN-verdrag Handicap: Inclusief Onderwijs, § 28. 
Hof strenger toetsen in zaken waarin de nationale rechters niet afdoende optreden.

Vraag is wat de impact is van deze zaak op hangende zaken. Net als bij Dupin t. Frankrijk gaat het immers ook bij Stoian om een zaak die in een comité van drie rechters werd beoordeeld. ${ }^{108}$ Çam en Enver Şahin werden daarentegen telkens in een kamer (zeven rechters) uitgesproken. Deze laatste lijken dan ook meer gezag te hebben. Een andere zaak over onderwijs voor personen met een handicap (Lupica t. Italië) is momenteel nog hangende. ${ }^{109}$ Mogelijk brengt die meer uitsluitsel, zeker als die door een kamer of de Grote Kamer zou worden behandeld.

108. J. Lievens en M. Spinoy, 'Leerlingen met specifieke onderwijsbehoeften in Straatsburg. Maakt inclusief onderwijs school?', Nieuw Juridisch Weekblad 2019, p. 783. Vergelijk: C. Cojocariu, 'Stoian v. Romania: the Court's drift on disability rights intensifies', Strasbourg Observers 2019 https://strasbourgobservers.com/2019/09/05/stoian-v-romania-thecourts-drift-on-disability-rights-intensifies/.

109. EHRM, 59751/15 (Lupica/Italië), aanhangig gemaakt op 24 november 2015. 